\title{
Does follicular dominance occur in ewes?
}

\author{
M. A. Driancourt ${ }^{1}$, R. Webb ${ }^{2}$ and R. C. Fry ${ }^{3}$ \\ ${ }^{1}$ INRA, Reproductive Physiology, 37380 Nouzilly, France; ${ }^{2}$ AFRC, Institute of Animal Physiology \\ and Genetics Research, Edinburgh Research Station, Roslin, Midlothian EH25 9PS, UK; and \\ ${ }^{3}$ Animal Research Institute, Werribee, VIC 3030, Australia
}

\begin{abstract}
Summary. The process by which a single follicle is selected to ovulate while others regress is unknown in ewes. If the dominant follicle secretes substances that directly inhibit the growth of other follicles, the superovulatory response to the administration of exogenous gonadotrophins may be blunted. Administration of $1250 \mathrm{iu}$ pregnant mares' serum gonadotrophin (PMSG) before or after the emergence of the dominant follicle in the follicular phase, or 1000 iu PMSG in the presence or absence of a large healthy or atretic follicle during the luteal phase did not affect the induced ovulatory response. Comparisons between the ovary with or without the dominant follicle did not reveal any differences in ovulatory response to PMSG. The in-vitro features (i.e. mitotic index, oestradiol and testosterone production) of follicles ipsilateral or contralateral to the dominant follicle during the early and late follicular phases were also similar.

If the dominant follicle secretes substances detrimental to the other follicles, this could be mimicked in vitro. Co-culture of small follicles with the largest follicles in a closed system did not reduce their incorporation of ${ }^{3} \mathrm{H}$ thymidine in granulosa cells, compared with small follicles cultured alone.

These data suggest that dominance is probably not operative in sheep. The administration of 500 iu of PMSG during the midfollicular phase increased ovulation rate in Merino ewes, indicating that dominance is essentially passive in ewes and can easily be overcome by raising gonadotrophin concentration.
\end{abstract}

Keywords: follicle; ovulation; gonadotrophin; paracrine regulation; sheep

\section{Introduction}

Although several large healthy follicles are growing within the ovary at the time of luteal regression in monotocous species, only one usually matures and ovulates, while the others become atretic (monkey: di Zerega \& Hodgen, 1981; cow: McNatty et al., 1984; ewe: Driancourt \& Cahill, 1984). This ovulatory or 'dominant' follicle has been identified in different species using different criteria, including increasing size (monkey: Clark et al., 1979; cow: Dufour et al., 1972; ewe: Driancourt \& Cahill, 1984), asymmetry in the pattern of secretion of oestradiol between the two ovaries (monkey: di Zerega et al., 1981; ewe: England et al., 1981) and its capacity to bind luteinizing hormone (LH) to the thecal and granulosa cells (monkey: Zeleznik et al., 1981; ewe: Webb \& England, 1982). The emergence of this dominant follicle has been associated with a reduced ovulatory response to exogenous gonadotrophins (monkey: di Zerega \& Hodgen, 1980; cow: Pierson \& Ginther, 1988), while its removal delays ovulation (monkey: Goodman et al., 1977; cow: Matton et al., 1981; ewe: Findlay \& Cumming, 1977).

The aim of the following experiments was to investigate whether the presence of the dominant follicle in Merino or Merino-cross ewes influenced other follicles directly or indirectly via secretion of compounds having a negative feedback action on follicle-stimulating hormone (FSH) secretion 
(Martin et al., 1988). The importance of an active mechanism was investigated by testing whether (i) the presence of a dominant follicle blunted the ovulatory response to pregnant mares' serum gonadotrophin (PMSG) (Exp. 1), (ii) the health of the largest follicle affected the ovulatory response to PMSG during the luteal phase (Exp. 2) and (iii) the influence of the dominant follicle on the morphological and functional characteristics of smaller follicles was greater on the ipsilateral ovary than in the contralateral ovary (Exp. 3); and by assessing the changes in cell division in follicles induced by co-culture with a large follicle (Exp. 4). Finally, the importance of a mechanism acting by controlling the release of FSH was investigated by supplying gonadotrophins when the ovulatory follicle was normally selected (Exp. 5).

\section{Materials and Methods}

Animal. All studies were conducted on Merino (Exps 1, 2, 4 and 5) or Merino-cross (Exp. 3) ewes because, even within nonprolific breeds, there may be differences in the processes regulating the differentiation of the ovulatory follicle (M. A. Driancourt \& R. C. Fry, unpublished). In Exp. 5, Finn and Romanov ewes were included for comparison.

Experiment 1: influence of the dominant follicle on PMSG-stimulated ovulation rate in the follicular phase. During the 1988 breeding season, the oestrous cycles of 60 parous Merino ewes at the Animal Research Institute, Werribee, Australia were synchronized (14-day progestagen pessary; Repromap: UpJohn, Rydalmere, NSW Australia). The ewes were randomly allocated to 5 groups $(n=12)$ and injected (i.m.) with 1250 iu PMSG (i.e. a mildly superovulatory dose: see results) (Folligon: Intervet, Australia) at either 0 (Group 1), 6 (Group 2), 12 (Group 3), 24 (Group 4) or $36 \mathrm{~h}$ (Group 5) after pessary withdrawal. The number and size of follicles $>2 \mathrm{~mm}$ in diameter on each ovary was obtained by laparoscopy (Roberts, 1968) at the time of PMSG administration. Follicles were classified as $<3,3-6$ or $>6 \mathrm{~mm}$ in diameter by direct comparison with probes $3 \mathrm{~mm}$ or $6 \mathrm{~mm}$ wide. Ewes were run with a ram twice a day (08: 00 and $17: 00 \mathrm{~h}$ ) from $24 \mathrm{~h}$ after pessary withdrawal, to determine the onset of behavioural oestrus. Ovulation rates were determined by counting the number of corpora lutea at a second laparoscopy 7 days after pessary withdrawal.

Experiment 2: infiuence of the largest healthy or atretic follicle on PMSG-induced ovulation rate in the luteal phase. Oestrus (Day 0 ) was detected in 40 parous Merino ewes following a 14-day progestagen pessary treatment during the 1987 breeding season at the Animal Research Institute, Werribee. The ewes were randomly divided into 4 groups. On Day 4 of the oestrous cycle the ewes in Groups 1 and 2 underwent their first laparotomy and had the single largest ovarian follicle labelled with indian ink (Driancourt \& Cahill 1984). The ewes in Groups 3 and 4 had the same treatment performed on Day 6 of the oestrous cycle. Also on Day 6, Groups 1 and 2 underwent a second laparotomy, the labelled follicle being remeasured and either ablated by electrocautery (Group 1) or left intact (Group 2). Immediately after surgery, these ewes received 1000 iu PMSG (i.m.) (a mildly superovulatory dose: see Results). The ewes in Groups 3 (cautery) and 4 (intact) received the same treatments, but on Day 9. All ewes received 750 iu human chorionic gonadotrophin (hCG) (i.m.) (Chorulon: Intervet, Australia) $48 \mathrm{~h}$ after their respective PMSG injections. The numbers of resulting corpora lutea were counted at laparoscopy 3 days later and young corpora lutea were identified according to Oldham \& Lindsay (1980).

Experiment 3: follicular development in the ovaries either ipsilateral or contralateral to the dominant follicle. The oestrous cycles of 16 Merino $\times$ Scottish Blackface ewes, maintained at the Large Animal Unit, Institute of Animal Physiology and Genetics Research, Edinburgh, UK were synchronized with a 12-day intravaginal treatment with progestagen-impregnated pessaries (MAP, Veramix: UpJohn, Crawley, UK). On Day 10, all ewes received an injection (i.m.) of $125 \mu \mathrm{g}$ PGF-2 $\alpha$ analogue (Estrumate: ICI, UK) to induce CL regression. Half of the ewes were spayed at $12 \mathrm{~h}$ after PGF injection, and the other half at $36 \mathrm{~h}$ after injection. From these ewes, all ewes with one or two large oestrogenic follicles on a single ovary were selected retrospectively after assay for oestradiol production (Webb et al., 1989). In these ewes (6 and 5 Merino $\times$ Scottish Blackface ovariectomized at 12 and $36 \mathrm{~h}$ after luteolysis, respectively), all the follicles $>2 \mathrm{~mm}$ in diameter were carefully dissected from both ovaries and incubated individually for $2 \mathrm{~h}\left(2 \times 1 \mathrm{~h}\right.$ incubations) in $1 \mathrm{ml} \mathrm{M} 199$ plus $20 \mathrm{~mm}$ Hepes at $37^{\circ} \mathrm{C}$ in $95 \%$ air and $5 \% \mathrm{CO}_{2}$ (Webb \& England, 1982). The incubation medium was stored at $-20^{\circ} \mathrm{C}$ prior to assay for oestradiol and testosterone. After incubation the follicles were fixed in Bouin Hollande's solution, sectioned at a thickness of $10 \mu \mathrm{m}$, stained and examined microscopically. Because the oocyte was not always in the centre of the follicle, which could result in underestimation of follicle size and number of granulosa cells, these measurements were made in the histological section with the largest diameter and the results were calculated according to Pedersen (1970) and Gougeon (1981). All follicles were assessed as healthy or atretic using 5 pycnotic bodies amongst the granulosa cells to define the beginning of atresia. The mitotic index was calculated as the ratio between the number of cells undergoing cell division and the number of granulosa cells in the section studied.

Concentrations of oestradiol and testosterone in the culture media were determined in duplicate using assays previously described (Webb et al., 1985). All samples were measured in single assays. The intra-assay coefficients of variation were $8.7 \%$ for oestradiol and $14.6 \%$ for testosterone. The minimum detectable values for oestradiol and testosterone were 6.3 and $25.5 \mathrm{pg} / \mathrm{ml}$, respectively. 
Experiment 4: effect of co-culture of small or medium follicles with a dominant follicle. A possible effect of the dominant follicle on cell division of smaller follicles was also tested. The oestrous cycles of $14++$ Booroola Merino ewes were synchronized by the insertion of vaginal sponges (Chronogest: Intervet, France) for 14 days; $24 \mathrm{~h}$ after sponge withdrawal, the ewes were ovariectomized, the small follicles $(1.5-2.5 \mathrm{~mm}$ in diameter, the size at which mitotic index is still high according to Turnbull et al., 1977) and the large follicle ( $>5 \mathrm{~mm}$ in diameter) were dissected. When several large follicles were dissected from a ewe, the one with the highest vascularization, assessed under a dissecting microscope, was selected. All small follicles were randomly assigned to four groups: control, $100 \mathrm{ng} \mathrm{FSH} / \mathrm{ml}$ $($ CY 1746, activity $=38.2 \times$ FSH S$)$, large follicles ( 3 follicles $>5 \mathrm{~mm}$ in the culture well) and FSH + large follicles. Pools of small follicles corresponding to treatment groups were cultured for $4 \mathrm{~h}$ in 24 -well plates (Corning) in $4 \mathrm{ml}$ of Menezo medium devoid of thymine and supplemented with $5 \mu \mathrm{Ci}^{3} \mathrm{H}$ thymidine/ml (CEA Saclay) at $37^{\circ} \mathrm{C}$ in $95 \%$ air and $5 \% \mathrm{CO}_{2}$.

At the end of the incubation, the follicles were fixed in Bouin Hollande's fixative devoid of mercuric chloride and sectioned at $5 \mu \mathrm{m}$ thickness. After Feulgen staining, slides were prepared for autoradiography. After dipping in Ilford $\mathrm{K} 5$ emulsion diluted $1 / 1(\mathrm{v} / \mathrm{v})$ with distilled water, they were air dried and exposed for 10 days at $4^{\circ} \mathrm{C}$, then developed and counterstained with haematoxylin. For each healthy follicle, on its largest section, all labelled cells (i.e. with > 10 silver grains/cell) were counted. The number of granulosa cells in the section studied was obtained from antrum size, granulosa layer thickness and granulosa cell density. Large follicles were also checked for atresia using 5 pycnotic bodies to define the beginning of atresia.

Experiment 5: effect of raising gonadotrophin concentration during the midfollicular phase. The oestrous cycles of 10 ++ Booroola Merino, 9 Romanov and 8 Finn ewes were synchronized with a progestagen pessary treatment for 14 days ( $40 \mathrm{mg}$ FGA: Intervet, France) during the breeding season at INRA, Nouzilly, France. Ovulation rates for this control cycle were determined at laparoscopy 7 days after pessary withdrawal. Luteolysis was induced by a PGF- $2 \alpha$ analogue (125 $\mu \mathrm{g}$ Estrumate: ICI, France) injected (i.m.) on Day 12 of the next cycle and all ewes were treated with 500 iu of PMSG (Intervet, Angers, France) $24 \mathrm{~h}$ after luteolysis, Resulting ovulation rates were determined by laparoscopy 7 days after PGF-2 $\alpha$ treatment.

Statistical analysis. Treatment effects were assessed by one-way (Exp. 1) or two-way (Exps 2 and 4) ANOVA on raw or log-transformed data. Within-ewe differences (i.e. between ovary responses (Exp. 3) and between-cycle comparisons (Exp. 5)) were tested by paired $t$-tests. Differences in distribution were tested by the 2I test. All results are means \pm s.e.m.

\section{Results}

\section{Experiment 1}

The proportions of ewes having a follicle $>6 \mathrm{~mm}$ in diameter on either ovary were $9 / 12,9 / 12$, $6 / 12,10 / 11$ and $11 / 12$ for Groups $1,2,3,4$ and 5 , respectively $(2 I=7 \cdot 76 P=0 \cdot 1)$. All ewes contained follicles $>3 \mathrm{~mm}$ on their ovaries.

The interval between sponge removal and the administration of PMSG did not significantly influence the subsequent ovulation rate (Table 1). Grouping the data in early $(0,6$ and $12 \mathrm{~h}, n=32$ ewes ovulating) vs. late ( 24 and $36 \mathrm{~h}$ after luteolysis, $n=19$ ewes ovulating) did not produce a significant difference in PMSG-induced ovulation rate between these two timings (early $3.93 \pm 0.42$, late $3 \cdot 10 \pm 0.52$ ). Oestrus was detected $\sim 56.7 \mathrm{~h}$ after sponge removal in the ewes given PMSG at time 0. When PMSG was given 6, 12, 24 or $36 \mathrm{~h}$ after luteolysis, oestrus was delayed $3,10,14$ and $28 \mathrm{~h}$, respectively (Table 1).

Table 1. Ovulation rate and time from pessary withdrawal to oestrus in ewes administered $1250 \mathrm{iu}$ pregnant mares' serum gonadotrophin (i.m.) at 0 (Group 1), 6 (Group 2), 12 (Group 3), 24 (Group 4) and $36 \mathrm{~h}$ (Group 5) after pessary withdrawal

\begin{tabular}{|c|c|c|c|c|c|}
\hline & \multicolumn{5}{|c|}{ Group } \\
\hline & 1 & 2 & 3 & 4 & 5 \\
\hline Number ovulating & 11 & 11 & 10 & 9 & 10 \\
\hline Ovulation rate/ewe ovulating & $4.6 \pm 0.74$ & $3.2 \pm 0.69$ & $4 \cdot 0 \pm 0.78$ & $3.4 \pm 0.8$ & $2 \cdot 8 \pm 0.7$ \\
\hline Time to oestrus (h) & $57 \pm 5 \cdot 2^{\mathrm{a}}$ & $60 \pm 4 \cdot 3^{a}$ & $67 \pm 4 \cdot 0^{\mathrm{ab}}$ & $71 \pm 5 \cdot 5^{b}$ & $85 \pm 4 \cdot 8^{b}$ \\
\hline
\end{tabular}

Data are means \pm s.e.m.

Different superscripts denote significant differences $(P<0.05)$. 
Within-ewe comparisons showed no difference $(P=0 \cdot 34)$ in the PMSG-induced ovulation rate between the ovary possessing a follicle $>6 \mathrm{~mm}$ in diameter at the time of PMSG administration and its counterpart.

\section{Experiment 2}

During the pretreatment period, the mean diameter of the largest follicle in Groups 1 and 2 on Day 4 was $5.1 \pm 0.35 \mathrm{~mm}$, while on Day 6 it was $7.3 \pm 0.23 \mathrm{~mm}$. The mean growth rate of the largest follicle between Days 4 and 6 of the oestrous cycle (calculated for each individual follicle) was $0.9 \pm 0.2 \mathrm{~mm} /$ day. Most of the ink-labelled follicles were considered healthy on Day 6 as $83 \%$ had increased in diameter, while $11 \%$ had remained the same.

The mean diameter of the largest follicle in Group 3 and 4 ewes was $7 \cdot 3 \pm 0.41 \mathrm{~mm}$ on Day 6 , and then decreased in diameter at $0.4 \pm 0.1 \mathrm{~mm} /$ day to be $6.0 \pm 0.34 \mathrm{~mm}$ in diameter on Day 9 . Between Days 6 and 9,72\% of these follicles decreased in size while $6 \%$ remained the same, suggesting that by Day 9 most of these follicles were atretic or going atretic.

The mean ovulation rate of Group 1 (cautery) and Group 2 (sham) ewes in response to PMSG on Day 6 was $4.11 \pm 0.50$ and $3.56 \pm 0.78$, respectively, and $3.0 \pm 0.60$ and $4.56 \pm 0.63$ for Group 3 (cautery) and Group 4 (sham) ewes receiving PMSG on Day 9. The induced ovulation rates were not significantly affected by either the day of PMSG treatment or day of cautery of the largest follicle, although the interaction was close to significant $(P=0.07)$.

Within ewes, comparisons between the ovary containing either the intact or ablated large follicle and the contralateral ovary demonstrated that this interaction was due to a significant increase in ovulation rate in response to PMSG, when the largest follicle was present on Day 9 (Table 2).

Table 2. Ovulation rate after sham or cautery of the largest healthy (Day 6) or atretic (Day 9) follicle in ewes administered 1000 iu pregnant mares' serum gonadotrophin (i.m.)

\begin{tabular}{llcccc}
\hline & & & $\begin{array}{c}\text { Ipsilateral } \\
\text { ovary }\end{array}$ & $\begin{array}{c}\text { Contralateral } \\
\text { ovary }\end{array}$ & Probability \\
\hline Day 6 & Sham & 9 & $2.33 \pm 1.58$ & $1.22 \pm 1.64$ & $0 \cdot 169$ \\
& Cautery & 9 & $2.55 \pm 1.23$ & $1.55 \pm 0.88$ & 0.080 \\
Day 9 & Sham & 9 & $3.22 \pm 1.64$ & $1.33 \pm 1.22$ & 0.023 \\
& Cautery & 6 & $2.16 \pm 1.16$ & $1.50 \pm 1.22$ & 0.445 \\
\hline
\end{tabular}

Data are means \pm s.e.m.

\section{Experiment 3}

Twelve hours after luteolysis, the features of the smaller healthy follicles on the ovary containing the early dominant follicles $(5.91 \mathrm{~mm}$ and producing $2143 \mathrm{pg}$ oestradiol $/ \mathrm{ml} \mathrm{per} \mathrm{h}$ ), were not different from those of the smaller healthy follicles on the contralateral ovary (Table 3). Thirty-six hours after luteolysis, there were only 0 and 0.57 healthy follicles per ewe on the ovaries ipsilateral and contralateral to the actual dominant follicles $(6 \cdot 1 \mathrm{~mm}$ and producing $2589 \mathrm{pg}$ oestradiol $/ \mathrm{ml}$ per h), precluding comparisons between ovaries (Table 3). However, when the small follicles of the contralateral ovary were compared 12 and $36 \mathrm{~h}$ after luteolysis, the only parameter significantly reduced was the size of the healthy follicles $(P=0.02)$ (Table 3$)$.

\section{Experiment 4}

Of the 59 small follicles dissected from the ovaries, 33 were healthy at histological examination. All large follicles were healthy. The mean labelling index of the granulosa cells from small healthy follicles cultured alone, with FSH, with large follicles or with FSH and large follicles were 
Table 3. Features of the population of small follicles ( $\geqslant 2 \mathrm{~mm}$ in diameter) on ovaries ipsi- or contralateral to the dominant follicles in the early and late follicular phases in ewes

\begin{tabular}{|c|c|c|c|c|}
\hline & \multicolumn{2}{|c|}{ Early } & \multicolumn{2}{|c|}{ Late } \\
\hline & $\begin{array}{l}\text { Ipsilateral } \\
\text { ovary }\end{array}$ & $\begin{array}{l}\text { Contralateral } \\
\text { ovary }\end{array}$ & $\begin{array}{l}\text { Ipsilateral } \\
\text { ovary }\end{array}$ & $\begin{array}{c}\text { Contralateral } \\
\text { ovary }\end{array}$ \\
\hline Number of dominant follicles & $1 \cdot 5$ & - & 1.57 & - \\
\hline $\begin{array}{l}\text { Oestradiol produced by dominant follicles } \\
(\mathrm{pg} / \mathrm{ml} \text { per } \mathrm{h})\end{array}$ & $2143 \pm 217$ & - & $2589 \pm 284$ & - \\
\hline Diameter of dominant follicles $(\mathrm{mm})$ & $5.91 \pm 0.46$ & - & $6.07 \pm 0.41$ & - \\
\hline Total number of follicles dissected & $5.0 \pm 0.72$ & $5 \cdot 33 \pm 0 \cdot 61$ & $3.42 \pm 0.52$ & $4.42 \pm 0.57$ \\
\hline Number of healthy follicles & $1.0 \pm 0.44$ & $1.0 \pm 0.68$ & $\overline{0}$ & $0.57 \pm 0.56$ \\
\hline Diameter of healthy follicles (mm) & $3.41 \pm 0.26$ & $2 \cdot 91 \pm 0 \cdot 22$ & - & $2 \cdot 12 \pm 0.07$ \\
\hline Mitotic index of healthy follicles (\%) & $2 \cdot 37 \pm 0.80$ & $2 \cdot 23 \pm 0.40$ & - & $1.56 \pm 0.51$ \\
\hline \multicolumn{5}{|l|}{ Production of healthy follicles $(\mathrm{pg} / \mathrm{ml}$ per $\mathrm{h}$ ) } \\
\hline Oestradiol & $67 \cdot 5 \pm 13 \cdot 1$ & $49 \pm 17 \cdot 5$ & - & $14.7 \pm 8.4$ \\
\hline Testosterone & $2150 \pm 583$ & $2116 \pm 368$ & - & $1100 \pm 265$ \\
\hline
\end{tabular}

$0 \cdot 18 \pm 0.04(n=10), 0 \cdot 13 \pm 0.02 \quad(n=7), 0 \cdot 21 \pm 0.07 \quad(n=8)$ and $0 \cdot 15 \pm 0.06 \quad(n=8)$ respectively. There were no significant differences between groups.

\section{Experiment 5}

The mean ovulation rate of the 10 Booroola Merino ewes in the control cycle was $1 \cdot 1 \pm 0.03$ and significantly increased $(P<0.01)$ after the administration of 500 iu of PMSG $24 \mathrm{~h}$ after luteolysis, to $2 \cdot 4 \pm 0 \cdot 3$. The ovulation rate increased in 8 of 10 ewes. In contrast, a similar dose of PMSG had no effect on ovulation rate in Romanov (control cycle $3.78 \pm 0.28$, treated cycle $3.22 \pm 0.40$ ) and Finn ewes (control cycle $2 \cdot 38 \pm 0 \cdot 23$, treated cycle $2 \cdot 38 \pm 0 \cdot 27$ ).

\section{Discussion}

In ewes, the presence of the dominant follicle did not significantly affect the PMSG-induced ovulation rate or the parameters of morphological (size, atresia) and functional differentiation (steroidogenesis) within the ovary in vivo. This was demonstrated using between-ewe and withinewe comparisons. Furthermore, in vitro, no inhibitory effects of the dominant follicle on cell division were observed. Thus, using several criteria, a direct effect of the dominant follicle on the growth of the other follicles was not identified in sheep, suggesting that it is not of major importance in the control of ovulation rate in Merino ewes.

The between-ewe comparisons studied the ovulation rates induced by PMSG in the presence or absence of the dominant follicle at different stages of the oestrous cycle. During the follicular phase (Exp. 1) the ovulation rates resulting from a single injection of PMSG (1250 iu) at either 0, 6, 12, 24 or $36 \mathrm{~h}$ after luteolysis did not differ significantly. As PMSG has a limited ability to rescue atretic follicles in ewes (Driancourt et al., 1987), it is likely that ovulation rate measures recruitment of new follicles and not recovery of old ones from atresia. That PMSG was administered in the periods before and after selection of the dominant follicle is based on the following evidence. Firstly, McNatty et al. (1982) showed that a large ( $>5 \mathrm{~mm}$ diameter) oestrogenic (secreting $>1 \mathrm{ng}$ oestradiol/min) follicle appeared about $10 \mathrm{~h}$ after cloprostenol-induced luteolysis in Romney ewes. Secondly, ink labelling of follicles and following their progression during the follicular phase in Corriedale ewes, by Driancourt \& Cahill (1984), showed that the proportion of ewes in which the largest follicle was the ovulatory one increased from 0 at the time of luteolysis, $1 / 7$ at $4 \mathrm{~h}, 1 / 7$ at $8 \mathrm{~h}$, $4 / 7$ at $12 \mathrm{~h}$ and $4 / 7$ at $24 \mathrm{~h}$ to $5 / 7$ at $48 \mathrm{~h}$ after luteolysis. Thirdly, in Exp. 1, a lower proportion of 
ewes possessed a follicle $>6 \mathrm{~mm}$ in diameter at 0,6 and $12 \mathrm{~h}$ following luteolysis than at 24 and $36 \mathrm{~h}$ and many of these were likely to be atretic (Driancourt \& Cahill, 1984). Although there is obviously wide variability between ewes in the timing of selection of the dominant follicle, all these data indicate that the dominant follicle emerges at $\sim 12-24 \mathrm{~h}$ after luteolysis. However, after grouping the ewes into early $(0,6$ and $12 \mathrm{~h})$ and late ( 24 and $36 \mathrm{~h})$ follicular-phase groups, there was again no difference in PMSG-induced ovulation rate. An unexpected finding was that oestrus was significantly delayed by the administration of PMSG during the late follicular phase (Table 1). The reason why PMSG did not induce an early oestrus, as it usually does, is unclear.

These results obtained in the follicular phase were confirmed by Exp. 2 performed during the luteal phase. The presence or absence of a large healthy follicle at Day 6 and the presence or absence of a large atretic follicle at Day 9 did not influence the ovulation rate induced by PMSG + hCG. Overall, our results in sheep are in contrast with those in monkeys (di Zeraga \& Hodgen, 1980) and cows (Saumande et al., 1978; Pierson \& Ginther, 1988; Grasso et al., 1989) where the superovulatory response to exogenous gonadotrophins was lower in the presence of a large dominant follicle. This highlights species differences in the mechanisms controlling selection of the ovulatory follicles.

The results discussed so far are supported by the within-ewe comparisons, which assume that a substance or factor synthesized and released by the dominant follicle has a greater effect on the ipsilateral ovary than contralateral ovary, through simple diffusion principles. For example, follicle regulatory protein (FRP) is only detected in the ovarian venous blood from the ovary bearing the largest follicle in primates (di Zerega et al., 1983). We were unable to detect any significant differences in either the ovarian response to PMSG (Exps 1 and 2) or the morphological and functional development of follicles $>2 \mathrm{~mm}$ diameter (Exp. 3) between the ovary ipsilateral and contralateral to the dominant follicle, whether in the follicular or luteal phase. Interestingly, the presence of the large atretic follicle on the ovary at Day 9 of the oestrous cycle increased the ovulatory response to PMSG (Table 2). While this stimulation by the atretic follicle needs to be confirmed, it may explain, in part, the reported renewal of waves of follicular growth during the luteal phase (ewe: Driancourt et al., 1988; cow: Savio et al., 1988; Sirois \& Fortune, 1988).

Finally, we tried to mimic follicular dominance in vitro by assessing possible inhibitory effects of the dominant follicle on cell division of small follicles. Such regulations were suggested by the demonstration of inhibitors of cell division in ovine follicular fluid (Cahill et al., 1985; Carson et al., 1988). We could not identify any direct effect of the dominant follicle on the smaller follicles after co-culture.

Using in-vivo and in-vitro techniques, we did not find any evidence to support the notion that overt dominance by the preovulatory follicle is significant in Merino ewes. This raises the question of other possible mechanisms involved in the selection of the ovulatory follicle. One possibility is the change in FSH concentrations which occurs in the mid late follicular phase due to the secretion of oestradiol and/or inhibin from the largest healthy follicle (Martin et al., 1988). Indeed, when FSH concentrations were supplemented with small amounts of PMSG at this time (Exp. 5), ovulation rates increased significantly. Nevertheless, these results are at variance with 2 similar studies in ewes. Henderson et al. (1988) increased ovulation rates in Romney ewes with the infusion of ovine FSH preparations with either very high or very low LH contamination during the entire follicular phase, but not when the infusions were restricted to the late follicular phase. The differences between the various studies may be due to the requirement of an optimal FSH:LH ratio to act on selection. This is supported by the observation that in ++ Booroola Merino ewes, the injection of $3 \mathrm{mg}$ of pFSH (FSH:LH $=3$ ) at $24 \mathrm{~h}$ and $36 \mathrm{~h}$ following luteolysis does not alter ovulation rate (M. A. Driancourt and R. C. Fry, unpublished results). Neither Romanov nor Finn ewes demonstrated increased ovulation rate following PMSG administration, suggesting that their high ovulation rate may be independent of gonadotrophin support during most of the follicular phase. This is in good agreement with previous data on Finn (Webb \& Gauld, 1985) and Romanov ewes (Driancourt et al., 1988). 
In conclusion, selection of the ovulatory follicle in Merino ewes contrasts with the situation in humans and cattle where compounds secreted by the dominant follicle and gonadotrophic stimulation appear to interact in the control of follicular selection. This may explain why it is much more difficult to manipulate ovarian function in cattle than in sheep. For example, both active and passive immunization against ovarian steroids lead to significant increases in ovulation rate in sheep (Scarramuzzi et al., 1977; Land et al., 1982), but not in cattle (Sreenan et al., 1987; Price et al., 1987; Webb \& Morris, 1988).

\section{References}

Cahill, L.P., Driancourt, M.A., Chamley, W.A. \& Findlay, J.K. (1985) Role of intrafollicular regulators and FSH in growth and development of large antral follicles. $J$. Reprod. Fert. 75, 599-607.

Carson, R.S., Robertson, D.M. \& Findlay, J.K. (1988) Ovine follicular fluid inhibits thymidine incorporation by 3 T3 fibroblasts in vitro. J. Reprod. Fert. 82, 447-455.

Clark, J.R., Dierschke, D.J. \& Wolf, R.C. (1979) Hormonal regulation of ovarian folliculogenesis in rhesus monkeys. Serum concentration of oestradiol-17 $\beta$ and follicle-stimulating hormone associated with growth and identification of the preovulatory follicle. Biol. Reprod. 21, 497-50.

di Zerega, G.S. \& Hodgen, G.D. (1980) The primate ovarian cycle: suppression of hMG induced follicular growth in the presence of the dominant follicle. $J$. clin. Endocr. Metab. 50, 819-825.

di Zerega, G.S. \& Hodgen, G.D. (1981) Folliculogenesis in the primate ovarian cycle. Endocr. Rev. 2, $27-49$.

di Zerega, G.S., Lynch, A. \& Hodgen, G.D. (1981) Initiation of asymetrical ovarian estradiol secretion in the primate ovarian cycle after lutectomy. Endocrinology 108, 1233-1236.

di Zerega, G.S., Marrs, R.P., Roche, P.C., Campeau, J.D. \& Kling, O.R. (1983) Identification of proteins in pooled human follicular fluid which suppress follicular response to gonadotrophins. J. clin. Endocr. Metab. 56, 35-41.

Driancourt, M.A. \& Cahill, L.P. (1984). Preovulatory events in sheep. J. Reprod. Fert. 71, 205-211.

Driancourt, M.A., Fry, R.C., Clarke, I.J. \& Cahill, L.P. (1987) Follicular growth and regression during the 8 days after hypophysectomy in sheep. J. Reprod. Fert. $79,635-641$.

Driancourt, M.A., Philipon, P., Locatelli, A., Jacques, A. \& Webb, R. (1988) Are differences in FSH concentrations involved in the control of ovulation rate in Romanov and Ile de France ewes? J. Reprod. Fert. 83, 509-516.

Dufour, J., Whitmore, H.L., Ginther, O.J. \& Casida, L.E. (1972) Identification of the ovulating follicle by its size on different days of the oestrous cycle in heifers. J. Anim. Sci. 34, 85-87.

England, B.G., Webb, R. \& Dahmer, M.K. (1981) Follicular steroidogenesis and gonadotropin binding to ovine follicles during the estrous cycle. Endocrinology 109, 881-887.

Findlay, J.K. \& Cumming, I.A. (1977) The effect of unilateral ovariectomy on plasma gonadotropin levels, estrus and ovulation rate in sheep. Biol. Reprod. 17, 178-183.
Goodman, A.L., Nixon, W.E., Johnson, D.K. \& Hodgen, G.D. (1977) Regulation of folliculogenesis in the cycling rhesus monkey: selection of the dominant follicle. Endocrinology 100, 155-161.

Gougeon, A. (1981) Cinétique de croissance des follicules ovariens pendant le cycle menstruel chez la femme. D.Sc. thesis. University of Paris VI.

Grasso, F., Guilbault, L.A., Roy, G.L., Matton, P. \& Lussier, J.G. (1989) The influence of the presence of a dominant follicle at the time of initiation of a superovulatory treatment on superovulatory responses in cattle. Theriogenology 31, 199.

Henderson, K.M., Savage, L.C, Ellen, R.L., Ball, K. \& MeNatty, K.P. (1988) Consequences of increasing or decreasing plasma FSH concentrations during the preovulatory period in Romney ewes. J. Reprod. Fert. 84, 187-196.

Land, R.B., Morris, B.A., Baxter, G., Fordyce, M. \& Forster, J. (1982) Improvement of sheep fecundity by treatment with antisera to gonadal steroids. $J$. Reprod. Fert. 66, 625-634.

McNatty, K.P., Gibb, M., Dobson, C., Ball, K., Heath, D. \& Thurley, D.C. (1982) Preovulatory follicular development in sheep treated with PMSG and/or prostaglandin. J. Reprod. Fert. 65, 111-123.

McNatty, K.P., Heath, D.A., Henderson, K.M., Lun, S., Hurst, P.R., Ellis, L.M., Montgomery, G.W., Morrison, L. \& Thurley, D.C. (1984). Some aspects of thecal and granulosa cell function during follicular development in the bovine ovary. J. Reprod. Fert. 72, 39-53.

Martin, G.B., Price, C.A., Thiery, J.C. \& Webb, R. (1988) Interactions between inhibin, oestradiol and progesterone in the control of gonadotrophin secretion in the ewe. J. Reprod. Fert. 82, 319-328.

Matton, P., Adelakoun, V., Couture, Y. \& Dufour, J.J. (1981) Growth and replacement of the bovine ovarian follicles during the oestrous cycle. J. Anim. Sci. 52, 813-820.

Oldham, C.M. \& Lindsay, D.R. (1980) Laparoscopy in the ewe: a photographic record of the ovarian activity of ewes experiencing normal or abnormal oestrous cycles. Anim. Reprod. Sci. 3, 119-129.

Pedersen, T. (1970) Follicle kinetics in the ovary of the cyclic mouse. Acta endocr., Copnh. 64, 304-323.

Pierson, R.A. \& Ginther, O.J. (1988) Follicular populations during the oestrous cycle in heifers. III. Time of selection of the dominant follicle. Anim. Reprod. Sci. 16, 81-95.

Price, C.A., Morris, B.A. \& Webb, R. (1987) Reproductive and endocrine effects of active immunization against a testosterone conjugate in the heifer. $J$. Reprod. Fert. 81, 149-160. 
Roberts, E.M. (1968) Endoscopy of the reproductive tract of the ewe. Proc. Aust. Soc. Anim. Prod. 7, 192-194.

Savio, J.D., Keenan, L., Boland, M.P. \& Roche, J.F. (1988) Pattern of growth of dominant follicles during the oestrous cycle in heifers. J. Reprod. Fert. 83, $663-671$.

Scaramuzzi, R.J., Davidson, W.G. \& Van Look, P.F.A. (1977) Increasing the ovulation rate of sheep by active immunization against an ovarian steroid androstenedione. Nature, Lond. 269, 817-818.

Saumande, J., Chupin, D., Mariana, J.C., Ortavant, R. \& Mauléon, P. (1978) Factors affecting the variability of ovulation rates after PMSG stimulation. In Control of Reproduction in the Cow, pp. 195-225. Ed. J.M. Sreenan. Martinus Nijhoff, The Hague.

Sirois, J. \& Fortune, J.E. (1988) Ovarian follicular dynamics during the estrous cycle in heifers monitored by real-time ultrasonography. Biol. Reprod. 39, 308-317.

Sreenan, J.M., Morris, D., Tait, A. \& Diskin, M.G. (1987) Manipulation of the immune system to increase ovulation rate in the cow. In Follicular Growth and Ovulation Rate in Farm Animals, pp. 73-86. Eds J. F. Roche \& D. O'Callaghan. Martinus Nijhoff, Dordrecht.

Turnbull, K.E., Braden, A.W.H. \& Mattner, P.E. (1977) The pattern of follicular growth and atresia in the ovine ovary. Aust. J. Biol. Sci. 30, 229-241.

Terqui, M. (1978) Contribution à l'étude des oestrogènes chez la brebis et la truie. D.Sc. thesis, Paris VI.
Webb, R. \& England, B.G. (1982). Identification of the ovulatory follicle in the ewe: associated changes in follicular size, thecal and granulosa cell luteinizing hormone receptors, antral fluid steroids and circulating hormones during the preovulatory period. Endocrinology 110, 873-881.

Webb, R. \& Gauld, I.K. (1985) Folliculogenesis in sheep: control of ovulation rate. In Genetics of Reproduction in the Sheep, pp. 261-274. Eds R. B. Land \& D. W. Robinson. Butterworths, London.

Webb, R. \& Morris, D. (1988) The effects of steroid and inhibin immunity on FSH and ovulation. Proc. 11th Int. Congr. Anim. Reprod. and AI, vol 5, pp. 183-191. University College, Dublin, Ireland.

Webb, R., Baxter, G., McBride, D., Nordblom, G.D. \& Shaw, M.P.K. (1985) The measurement of testosterone and oestradiol-17ß using iodinated tracers and incorporating an affinity chromatography extraction procedure. J. Steroid Biochem. 23, 1043-1051.

Webb, R., Gauld, I.K. \& Driancourt, M.A. (1989) Morphological and functional characterization of large antral follicles in three breeds of sheep with different ovulation rates. J. Reprod. Fert. 87, 243-255.

Zeleznik, A.J., Schuler, H.M. \& Reichert, L.E. (1981) Gonadotropin-binding sites in the rhesus monkey ovary: role of the vasculature in the selective distribution of human chorionic gonadotropin to the preovulatory follicle. Endocrinology 109, 356-362.

Received 14 July 1990 